\title{
Pendidikan Agama Islam antara Aksi dan Teori: Studi di MI Ma'arif Bego Yogyakarta
}

\author{
1* Herlina dan ${ }^{2}$ M. Khoirul hadi al-Asy'ari \\ ${ }^{1}$ Mahasiswa Pasca-Sarjana UIN Sunan Kalijaga Yogyakarta \\ 2 Dosen Fakultas Syari'ah IAIN Jember
}

\begin{abstract}
This paper is a paper that raises a theme related to the study of Islamic religious education, Islamic religious education between action and theory: the study of the development and implementation of Islamic religious education curriculum (Qur'an Hadith) in Ma'arif Bego Yogyakarta, using a descriptive normative approach there are three important questions how the concept of implementing Islamic education between action and implementation in MI maarif Bego Yogyakarta, the results of this study are an increase in student learning potential and student discussion from the results of the implementation of Islamic education.
\end{abstract}

Paper ini adalah paper yang mengangkat tema terkait dengan kajian pendidikan agama Islam MI, pendidikan agama Islam antara aksi dan teori : studi pengembangan dan implementasi kurikulum pendidikan Agama Islam (Qur'an Hadits) di MI Ma'arif Bego Yogyakarta, dengan menggunakan pendekatan normative diskriptif ada tiga pertanyaan penting bagaimana konsep implentasi pendidikan Agama Islam antara aksi dan implementasi di MI Maarif Bego Yogyakarta, hasil penelitian ini adalah adanya peningkatan terhadap potensi belajar siswa dan prestasi siswa dari hasil implemntasi pendidikan Agama Islam.

Keywords: MI (Madrasah Ibtidaiyah), Curriculum, Islamic Education.

\section{Latar Belakang}

Kurikulum sebagaimana esensinya merupakan seperangkat program yang dibuat oleh satuan pendidikan untuk mencapai tujuan pendidikan nasional. Dalam pendidikan, kurikulum diibaratkan seperti penentu arah untuk mencapai tujuan yang dimaksud. Namun penentu arah yang tersebut menurut Rustam Abong bukanlah satu-satunya penentu untuk meningkatkan mutu pendidikan. Ia juga menambahkan bahwa sebenarnya

* Corresponding author: Herlina ellynmustafa31@gmail.com

Published online at http://islamicinsights.ub.ac.id

Copyright (C) 2019 PSP2M UB Publishing. All Rights Reserved kurikulum dapat meningkatkan mutu dan kualitas peserta didik apabila didukung oleh kecakapan pendidik, ketercakupan substansi kurikulum dalam bahan ajar serta ketersedianya sarana prasarana dan kepemimpinan pendidikan (Rustam Abong, 2015). Dari pendapat tersebut, kurikulum dapat terealisasi sebab dukungan dari komponen lain. Untuk merealisasikan tujuan, maka dibutuhkan perencanaan yang meliputi berbagai hal, diantaranya: kurikulum, kelembagaan, manajemen, pendidik, peserta didik, alat, sarana dan prasarana, fasilitas, dan 
kebijakan pemerintah (Mujibur Rohman, 2015).

Kurikulum sebagai salah satu bagian penting dari pendidikan, maka sudah saatnya atau seharusnya update dan sesuai perkembangan zaman dan teknologi. Masalah yang kerap muncul dalam pendidikan dapat pula disebabkan kurikulum yang dirancang tidaklah sesuai dengan perekembangan era yang terus berganti.

Permasalahan tersebut kiranya penting untuk dicarikan solusi tepat serta mampu menunjang ketercapaian kompetensi peserta didik. Pendidikan pada esensinya membantu manusia hidup lebih baik lagi. Pendidikan dapat dikatakan pula sebagai ikon keberhasilan suatu wilayah maupun lembaga. Jadi, jika SDM memiliki perhatian yang dominan kepada pendidikan maka kemungkinan problem yang muncul dapat diminimalisir. Hadirnya pendidikan dalam kehidupan manusia dapat menyelamatkannya dari pengaruh-pengaruh tidak baik seperti perilaku yang tercela, dan lainnya. Dapat pula dengan melakukan peningkatan mutu pendidikan. Adapun peningkatan mutu yang dimaksud ialah dengan melakukan pengembangan kurikulum seperti kurikulum PAI.

Pengembangan kurikulum PAI dapat dilakukan dengan melakukan pertimbangan dari hasil analisis kebutuhan-kebutuhan masyarakat baik semisal kebutuhan hidup maupun mengembangkan diri sesuai dengan pendidikan. Untuk itu terdapat dua langkah yang dapat dilakukan dalam pengembangan kurikulum, yaitu: merumuskan visi misi dengan jelas dan menjabarkan kompetensi standar (Arif Hidayatullah, Wahidul Anam, 2017).
Pendidikan yang tidak menyertakan pengajaran agama akan melahirkan para ilmuan yang jauh dari Tuhannya. Ia hanya sebatas ilmuan yang jauh dari syari'at agama ibaratnya ia berilmu tapi tidak berakhlak. Hal itu justru bertentangan dengan ajaran agama dan juga tujuan pendidikan Islam di Indonesia (Juwairiyah, 2004). Dengan berdasar pada sila pertama yaitu "Ketuhanan yang Maha Esa," sila tersebut memposisikan bahwa beragama maupun pengajaran agama menjadi suatu hal yang urgen utamanya dalam pendidikan. Bertuhan artinya ia harus beragama dan beriman.

Dengan berlatar belakang problem di atas, dapat disimpulkan bahwa pengembangan dan implementasi kurikulum pendidikan agama Islam urgen dilakukan. Pengembangan tersebut dilakukan oleh MI Ma'arif Bego Yogyakarta dengan tujuan untuk menciptakan SDM yang kompeten dan mampu bersaing di era millennial ini, serta menjawab kebutuhan masyarakat. Oleh karena itu penulis melaktak lebur kaessahukan mini riset tentang pengembangan dan implementasi kurikulum PAI (Qur'an Hadits) kelas V di MI Ma'arif Bego Yogyakarta.

\section{Pengembangan Kurikulum}

Dalam pendidikan, istilah kurikulum dimaknai sebagai program pendidikan yang direncanakan dilaksanakan untuk mencapai tujuan pendidikan (Hidayat, 2013). Tujuan yang dimaksud baik itu tujuan pendidikan instruksional maupun tujuan nasional. Kurikulum juga diibaratkan sebagai penentu arah, akan menuju kemanakah suatu pendidikan. Sejalan dengan hal tersebut, jika terdapat problem dalam tubuh pendidikan maka pembenahannya dapat dilakukan di kurikulumnya. 
Kurikulum sejatinya hadir untuk menjawab segala problem, tantangan, dan kebutuhan masyarakat. Dari hal itu, maka pengembangan yang dilakukan harus merujuk pada kebutuhan dan minat peserta didik sebagai subjek pendidikan (Muhaimin, 2014). Hilda Taba menyatakan bahwa kurikulum merupakan a plan for learning, therefore, what is known about the learning process and the development of the individual has bearing on the shaping of a curriculum (Taba, 1962).

M. Hajar Dewantoro juga mengemukakan bahwa kerukulum merupakan pedoman bagi jenis, lingkup, dan urutan isi serta strategi proses pendidikan. Untuk mengetahui keurgenan kurikulum, juga dapat dilihat dari sisi fungsinya yaitu sebagai sumber konsep dan landasan teoritis bagi pengembangan kurikulum di institusi pendidikan (M. Hajar Dewantoro, 2003). Sedangkan menurut Allan C. Ornstein mendefinisikan kurikulum sebagai subject matter or content in terms of grade levels. People who adopt this definition emphasize the fact and concept particular subject areas (Allan C. Ornstein, 2009). Dari beberapa definisi tersebut maka dapat disimpulkan bahwa kurikulum merupakan serangkaian program yang dapat dijadikan sebagai pedoman atau penentu arah bagi proses pendidikan untuk mencapai tujuan.

Selanjutnya, kurikulum yang telah disusun perlu dilakukan pengembangan. Hal itu untuk memperkuat eksistensi kurikulum termasuk juga kurikulum PAI. Kurikulum PAI merupakan kurikulum yang penekanan mencari ilmu agama dengan didasarkan pada nilai-nilai akhlak dan pada Allah (Muhammad Irsad, 2016).

\footnotetext{
* Corresponding author: Herlina ellynmustafa31@gmail.com Published online at

Copyright @ 2019 PSP2M UB Publishing. All Rights Reserved
}

Sedangkan pengembangan kurikulum PAI dapat dipahami kegiatan untuk menghasilkan kurikulum PAI; kegiatan penyusunan, pelaksanaan, penilaian, dan penyempurnaan kurikulum PAI; dan proses untuk yang mengaitkan satu komponen dengan yang lainnya untuk menghasilkan kurikulum PAI yang lebih baik (Muhaimin, 2014).

Dalam proses pengembangan kurikulum di madrasah atau sekolah, dapat dilakukan dengan tiga tahapan, yaitu: tingkat nasional, tingkat lembaga, tingkat bidang studi (silabus) dan tingkat satuan bahasan atau rencana program pembelajaran (RPP) atau modul (pengembangan kurikulum tingkat kelas) (Zaini, 2009). Menurut Sedya Santoso, pengembangan kurikulum kurikulum di Madrasah Ibtidaiyyah dapat dikembangkan berdasarkan beberapa prinsip, yaitu: berpusat pada potensi, beragam dan terpadu, tanggap terhadap ilmu pengetahuan, relevan dengan kebutuhan kehidupan, menyeluruh dan berkesinambungan, belajar sepanjang hayat, dan seimbang antara kepentingan nasional dan daerah (Santoso, 2011).

Sedangkan menurut Ibnu Sina, kurikulum pendidikan dapat dikembangkan dengan beberapa prinsip, yaitu:

a) Jangan memulai pengajaran al-Qur'an kepada anak melainkan setelah anak mencapai tingkat kematangan akal dan jasmaniah yang memungkinkan dapat menerima hal-hal yang diajarkan.

b) Mengintegrasikan antara pengajaran al-Qur'an dengan huruf hijaiyah, yang memperkuat pandangan pendidikan modern saat ini yaitu dengan metode campuran antara metode analitis dan 
strukturalis dalam mengajar membaca dan menulis.

c) Anak diajarkan pengetahuan agama ketika anak mencapai umur yang matang dan mantap menurut adat kebiasaan keagamaan yang benar hingga menyerap ke jiwanya.

d) Ibnu Sina juga memandang penting pelajaran syair sebagai sarana pendidikan perasaan. Pengajaran diarahkan pada penelusuran minat dan bakat. Mendidik anak dengan menumbuhkan kemampuan beragama yang benar, dan lainnya (Katni, 2016).

Dari serangkaian uraian tersebut, pada hakikatnya pengemabangan kurikulum yaitu program yang direncanakan dan dilaksanakan untuk mencapai tujuan (Idi, 2014). Hollis Caswell juga menyatakan bahwa pengembangan kurikulum yang dilakukan hendaknya berpijak pada masyarakat mauoun pekrerjaan (society centered) dengan istilah lain pengembanagan kurikulum yang bersifat interaktif. Guru memiliki peran urgen semisal partisipasinya dalam penyususnan kurikulum, dan dalam merumuskan tujuan, memilih isi, mennetukan kegiatn belajar, desain kurikulum, dan menilai hasil (Ahid, 2006).

\section{Komponen-Komponen Kurikulum}

Komponen-komponen kurikulum meliputi tujuan, materi, metode dan evaluasi kurikulum (Gunawan, 2013). Pertama, Tujuan Kurikulum Tujuan kurikulum memiliki keterkaitan dengan tujuan pendidikan nasional. Tujuan pendidikan nasional bertujuan untuk mengembangkan potensi peserta didik supaya tumbuh dan berkembang menjadi manusia yang beriman dan bertakwa. Tujuan pendidikan menurut Ibnu Sina, tujuan yang harus diarahkan pada upaya mempersiapkan seseorang supaya dapat hidup ditengah masyarakat dan dapat hidup bersama-sama dengan pekerjaan yang sesuai dengan potensinya (Katni, 2016).

Sebagaimana yang telah diuraikan tersebut, tujuan juga harus mengacu kea rah pencapaian tujuan pendidikan nasional, seperti yang telah dirumuskan dalam UU RI no. 20 tahun 2003 SISDIKNAS pasal 3. Pendidikan nasional memiliki tujuan untuk mengembangkan potensi peserta didik supaya menjadi manusia yang beriman kepada Tuhan YME, berakhlak mulia, sehat jasmani dan rohani, cakap kreatif dan mandiri (Zaini, 2009).

Macam-macam tujuan pendidikan, ialah:

a) Tujuan pendidikan nasional

b) Tujuan institisuinal

c) Tujuan kurikuler

d) Tujuan instruksional (Zaini, 2009).

Kedua, Materi/isi Kurikulum Pada komponen ini, isi kurikulum pada hakikatnya mencakup pengetahuan ilmiah yang diberikan kepada peserta didik. Pengetahuan-pengetahuan yang diberikan haruslah disesuaikan dengan tigkat dan jenjang pendidikan, perkembangan yang terjadi dalam masyarakat, tuntutan dan kebutuhan masyarakat serta perkembangan ilmu pengetahuan dan teknologi (Mudlofir, 2012). Komponen materi kurikulum biasanya berupa materi bidang-bidang studi, semisal: Qur'an Hadits, Fiqh, Matematika, Bahasa Arab, Tasyri', dan lainnya yang disesuaikan dengan jenjang, jenis, dan jalur pendidikan yang ada dan dimuat dalam struktur kurikulum suatu lembaga (Idi, 2014). 
Dalam merancang isi kurikulum, perlu memperhatikan beberapa kriteria seperti yang dinyatakan oleh Ali Mudlofir, yaitu:

a. Isi kurikulum harus sesui, tepat, dan bermakna bagi perkembangan siswa dan sejalan dengan tahap perkembangan anak.

\section{b. Mencerminkan kenyataan sosial}

c. Mencapat tujuan komprehensif, artinya mengandung aspek intelektual, moral, social, dan skill secara integral.

d. Berisi bahan ajar yang jelas, teori, prinsip bukan ahanya sekadar informasi yang samar teorinya.

e. Dapat menunjang tercapainya tujuan pendidikan (Idi, 2014).

Ketiga, Metode Kurikulum untuk mencapai suatu tujuan perlu suatu langkah supaya dapat mencapai tujuan pendidikan dapat dikenal dengan istilah metode. Komponen metode memiliki keterkaitan dengan implementasi, oleh karenanya komponen ini dapat dikatakan penting. Komponen ini dimaknai dengan upaya untuk mengimplemnetasikan rencana yanag sudah disusun dalam kegiatan nyata supaya tujuan yang telah dirumuskan dapat tercapai secara optimal (Tim Pengembang MKDP, 2011).

Keempat, Evaluasi Kurikulum Definisi evaluasi dengan merujuk pada pernyataan Tyler merupakan upaya untuk menentukan tingkat perubahan yang terjadi pada hasil belajar (behavior). Ruang lingkupnya terbatas dan memiliki pengaruh yang sangat kuat pada pencapaian hasil belajar (S. Hamid Hasan, 2009). Evaluasi memiliki tujuan untuk merumuskan apa yang harus dilakukan dari hasil, mengumpulkan informasi, menyajikan informasi untuk menetapkan alternatif keputusan, menentukan tingkat keberhasilan dan kegagalan suatu kurikulum, mengembangkan alternative sebagai pemecahan masalah, dan memahami serta menjelaskan karakteristik suatu kurikulum dan pelaksanaannya (S. Hamid Hasan, 2009).

Komponen evaluasi juga dikatakan urgen, sebab berhasil atau tidaknya kurikulum dapat diketahui dari hasil evaluasi. Untuk itu evaluasi memiliki keterkaitan erat dengan komponen lainnya, evaluasi akan mennetukan tujuan kurikulum, materi bahan, dan proses belajar mengajar (Idi, 2014).

\section{Bentuk-Bentuk Kurikulum PAI}

Implementasi

Implementasi kurikulum dimaknai sebagai proses penerapan ide, konsep dan kebijakan kurikulum, dalam proses pembelajaran sehingga peserta didik memiliki kompetensi sebagai hasil interaksi dengan lingkungannya (Zaini, 2009). Implementasi Kurikulum tidak hanya sebatas pelaksanaan tetapi pelaksanaan yang mengandung perubahan. Supaya implementasi terlaksana dengan baik oleh karenanya terdapat lima pedoman pokok, yaitu: 1) Perubahan untuk meningkatkan pembelajaran siswa secara teknis dan ilmiah. 2) Inovasi keurikulum yang sukses mengharuskan perubahan struktur sekolah tradisional. 3) Perubahan harus bias dikelola dan dilaksanakan sebagaian besar guru. 4) Implementasi perubahan yang sukses harus bersifat organik dari pada birokratik: melalui pendekatan adaptif dengan mempertimbangkan maslaah besar yang dihadapi sekolah dan kondisi sekolah. 5) Kurikulum perlu fokus pada upaya, waktu, dan dana yang memadai dengan kegiatan yang jelas, 
konten yang yang rasional, dan pelaksanaan yang tepat sasaran (Rustam Abong, 2015).

Secara gasi besar menurut Zaini implementasi kurikulum dapat dilakukan dengan tiga pokok kegiatan, diantaranya pertama, Pengembangan program atau pengorganisasian kurikulum, yang meliputi: kalender pendidikan, diversifikasi kurikulum, penyususnan silabus, kegiatan kurikuler dan pendekatan pembelajaran, kegiatan ekstra kurikuler, tenaga guru sumber dan sarana belajar, bahasa pengantar,nilai-nilai pancasila dan pendidikan budi pekerti,akselerasi belajar, pengayaan dan remedial, bimbingan dan konseling pendidikan kedua, Pelaksanaan pembelajaran Dalam pembelajaran, guru selain memiliki tugas mengajar, ia juga harus mengkoordinasikan lingkungan supaya dapat tercipta perubahan perilaku peserta didik. Pelaksanaan pembelajaran yang dimaksud secara umum dapat dilakukan dengan tiga hal: pre tes, proses, dan post test. Ketiga, Evaluasi. Kegiatan evaluasi dapat dilakukan dengan beberapa kegiatan, yaitu: penilaian kelas, test kemampuan dasar, penialian akhir satuan pendidikan dan sertifikasi, benchmarking, penilaian program, peningkatan kualitas pembelajaran, dan inovasi kurikulum tingkat satuan pendidikan (Zaini, 2009).

Kurikulum dalam bentuknya, ada kurikulum aktual dan kurikulum tersembunyi. Kurikulum aktual biasanya berupa proses pembelajaran antara guru dan siswa di dalam kelas.biasanya bentuknya dari penerapan strategi dan media pembelajaran. Dalam pelaksanaannya, menurut Marsh seperti yang dikutip oleh Muhammad Nur Halim permasalahan yang sering muncul biasanya terlalu sedikitnya waktu guru untuk merencanakan, belajar praktik keterampilan baru, banyaknya tuntutan untuk bersaing dalam penerapan kurikulum tersebut. Kemudian solusi yang dpaat dilakukan ialah pengembangan komitmen, kemajuan untuk bereksperimen, serta pengembangan strategi dalam organisasi sekolah. Selain itu eksperimen materi dan strategi tertentu supaya menghasilkan keselarasan antara praktik kelas dengan pendnagan materi pelajaran yang harus diajarkan (Muhammad Nurhalim, 2014).

Kurikulum tersembunyi atau istilah dalam bahasa Inggrisnya the bidden curriculum dalam praktiknya dapat berupa pola kepemimpinan kelas, sopan santun, kewirausahaan, dan lainnya. Kurikulum tersembunyi merupakan kurikulum yang muncul sebagai bentuk hubungan social, antar peserta didik dengan peserta didik, peserta didik dengan guru, peserta didik dengan administrator, peserta didik dengan lingkungan, peserta didik dengan aturan atau segala sesuatu yang ada di sekolah (Muhammad Nurhalim, 2014).

$\begin{array}{cccr}\text { Menurut } & \text { Vallence dan } & \text { Kentli } \\ \text { sebagaimana } & \text { yang dikutip } & \text { oleh }\end{array}$
Muhammad Nur Halim bahwa kurikulum tersembunyi memiliki tiga dimensi, yaitu: konteks pendidikan, konteks yang terjadi melalui sekolah, dan tingkatan intersinonalitas dan ketersembunyian atau kedalaman yang diperoleh oleh siswa (Muhammad Nurhalim, 2014).

\section{Metode Mini Riset: Sebagai Pendekatan}

Penelitian ini merupakan penelitian lapangan dengan menggunakan pendekatan kualitatif. Pendekatan untuk memperoleh dan menemukan data secara mendalam terkait objek yang ingin dikaji. Data yang dimaksud baik berupa katakata tertulis maupun lisan dari orangorang dan perilaku yang diamati (Lexy J. Moelong, 2010). Penelitian ini berusaha mengkaji bagaimana pengembangan dan 
implementasi kurikulum PAI di MI Ma'arif Bego Sleman Yogyakarta. Adapun sumber data yang digunakan dalam penelitian ini meliputi: kata-kata atau tindakan, sumber tertulis, foto, gambargambar, dan selebihnya dokumendokumen lainnya (Lexy J. Moelong, 2010). Kemudian teknik pengumpulan data yang digunakan oleh penulis ialah

Pertama, Pengumpulan data dengan observasi. Penulis melakukan observasi ke lokasi yang hendak diteliti yakni di MI Ma'arif Bego yang masih termasuk kawasan Kabupaten Sleman, Yogyakarta untuk melihat dan mengamati hal-hal yang berkaitan dengan ruang, kegiatan, peristawa dan lainnya. Dalam proses mengamati, penulis tidak terlibat langsung dalam kegiatan subjek penelitian secara langsung.

Pengumpulan data dengan wawancara. Penulis melakukan wawancara mendalam untuk menemukan dan memahami pengetahuan seseorang yang terkait dengan kajiannya. Wawancara dilakukan dengan dasar untuk mengumpulkan data. Dengan wawancara, peneliti dapat menggali hal-hal yang diketahui oleh subjek yang diteliti dengan mengajukan pertanyaan sampai pada hal-hal yang tersembunyi. Dengan kata lain wawancara dilakukan kepada seseorangyang dianggap dapat memberikan data dan informasi sesuai dengan fokus dan tujuan penelitian, yaitu pengembangan dan implementasi kurikulum pendidikan agama Islam di MI Ma'arif bego Yogyakarta (M.Djunaidi Ghony dan Fauzan ALmanshur, 2014).

Penelitian ini dilaksanakan di MI Ma'arif Bego Yogyakarta yang terletak di Sembego, Maguwoharjo, Depok, Sleman, Yogyakarta. Penelitian ini dilaksanakan pada hari Senin, 10 Desember 2018 dengan meminta izin penelitian kepada kepala sekolah serta menggali informasi tentang gambaran pengembangan dan implementasi kurikulum di sekolah ini. Kemudian, dilanjutkan pada Jum'at, 14 Desember 2018 dengan mewawancarai guru PAI yaitu Bapak Nur Huda salah satu guru PAI pengampu mata pelajaran Qur'an Hadits kelas V MI.

\section{Gambaran umum Mi Ma'arif Bego: kondisi umum}

MI Ma'arif Bego merupakan salah satu sekolah dasar Islam. Madrasah tersebut didirikan pada tahun 1962 di Daerah Sambego Maguwoharjo, Sleman, Yogyakarta. Sebagaimana sekolah lainnya, madrasah ini memiliki visi dan misi madrasah.

\section{Visi Madrasah}

Adapun visinya yaitu terwujudnya generasi Yang memiliki aqidah kuat, akhlak mulia serta unggul, mandiri dan berwawasan lingkungan. diantara Indikator-indikatornya ialah :

1. Terwujudnya prestasi akademis dan non akademis yang tinggi

2. Terwujudnya daya saing dengan sekolah lain yang tinggi

3. Terwujudnya sistem penilaian yang bermakna

4. Terwujudnya tenaga pendidik, sarana dan prasarana kependidikan yang berkwalitas

5. Terwujudnya proses pembelajaran yang berkwalitas

6. Terwujudnya keterjangkauan pembiayaan.

7. Terwujudnya manajemen yang terbuka. 
8. Terwujudnya siswa berwawasan lingkungan dengan pemanfaatan pengelolaan sampah dan pengelolaan limbah air serta membiasakan hidup hemat air dan hemat energi listrik.

\section{Visi Madrasah}

1. Memantapkan dan mengembangkan Madrasah sehingga memiliki jati diri ke Islaman

2. Menyelenggarakan pendidikan dan pengajaran yang bermutu sesuai dengan perkembangan ilmu pengetahuan dan teknologi.

3. Menjalin kerjasama dengan berbagai pihak dalam rangka pengembangan dan kemajuan Madrasah

4. Memanfaatkan alam sekitar dalam rangka meningkatkan wawasan lingkungan dan memupuk kecintaan terhadap tanaman serta menciptakan lingkungan yang nyaman dan asri.

5. Membiasakan hidup bersih dan sehat di lingkungan madrasah

6. Membiaskan hidup hemat air,energi listrik

7. Menyelenggarakan pengelolaan sampah dan pengelolaan air limbah serta membiasakan hidup hemat air dan hemat energi.

\section{Tujuan Madrasah}

1. Memberikan bekal dasar siswa agar menjadi manusia Muslim yang bertaqwa, berakhlak mulia, cakap dan percaya diri, cinta tanah air, menuju terwujudnya masyarakat adil dan makmur yang diridlohi Allah SW'T.

2. Mengembangkan potensi siswa secara menyeluruh dan seimbang meliputi aspek koknitif, afektif dan pesekhomotorik.

3. Menyiapkan siswa agar dapat mengikuti pendidikan di SLTP dengan kesiapan yang optimal.

4. Menyiapkan siswa yang berwawasan lingkungan dengan pemanfaatan pengolahan sampah dan pengolahan limbah air serta membiasakan hidup hemat air dan hemat energi listrik.

\section{Hasil analisis data: pengembangan kurikulum Pai Di Mi Ma'arif Bego}

Perkembangan kurikulum sebagaimana yang dikatakan oleh Audrey Nicholls dan Howard Nicholls, dan sebagaimana dikatakan pula oleh Oemar Hamalik bahwa pengembangan kurikulum merupakan perencanaan kesempatan belajar yang ditujukan untuk membawa peserta didik pada peruabahan yang dikehendaki dan menilai sejauh mana perubahan tersebut terjadi pada peserta didik (Syamsul Bahri, 2011).

Dalam pengembangan kurikulum PAI (Qur'an Hadits) kelas V di MI Ma'arif Bego dapat dikatakan belum signifikan. Proses pengembangannya masih mengalami kesulitan. Meski pada hakikatnya pengembangan kurikulum merupakan hal yang urgen hanya saja guru perlu waktu serta membutuhkan SDM yang mumpuni dibidang tersebut. Salah satu faktornya dapat disebabkan oleh keadaan lapangan menyatakan bahwa perbedaan antara jumlah guru dengan murid antara 500 siswa dan 22 guru masih kurang begitu merata. Hal itu yang menyebabkan pengembangan kurikulum PAI dikatakan belum mumpuni (Wawancara Nur Huda, 2018). 
Disisi lain, pengembangan tersebut juga nampak di program-program seperti program di luar kelas yakni "Majelis Tahfidz Qur'an" yang diadakan 1 tahun sekali oleh pihak sekolah, hal itu dimaksudkan untuk membumikan alQur'an. Adanya program tersebut, juga mendorong peserta didik untuk mencintai al-Qur'an dan bersemangat menjadi bagian di dalam program tersebut.

Pengembangan kurikulum juga diterapkan sebagaimana misi sekolah yang salah satunya "memanfaatlan alam sekitar dalam rangka meningkatkan wawasana lingkungan dan memupuk kecintaan terhadap tanaman serta menciptakan lingkungan yang aman dan asri." Dari visi tersebut, maka program-program yang dilasanakan semisal menanam bersama tumbuhan sejenis tumbuhan bunga yang dilakukan oleh guru bersama-sama dengan peserta didiknya.

Dalam pembelajaran PAI, guru juga berusaha memotivasi peserta didik untuk semangat membaca buku, serta bersikap lemah lembut atau dengan istilah lain menjadi suri tauladan bagi peserta didiknya agar tercapai tujuan dari sekolah. Menurut asumsi salah satu guru PAI, dengan demikian peserta didik menjadi lebih mudah memahami hal yang disampaikan guru (Wawancara Nur Huda, 2018).

\section{Analisis implementasi kurikulum PAI di MI Ma'arif Bego}

Menjadi guru tidak hanya memiliki tugas mengajar atau menyampaikan ilmu. Terdapat beberapa hal yang harus dilakukan oleh guru sebelum ia pergi mengajar ke lembaga, salah satunya ialah penyusunan RPP. RPP merupakan program pelaksanaan pembelajaran yang dibuat oleh guru dalam melaksanakan pembelajaran secara periodik, rencana ini harus supaya disusun setiap sebelum mengajar. Adapun tujuannya supaya kegiatan pembelajaran menjelas jelas dan terarah sehingga kegiatan tersebut dapat lebih terfokus dan target keberhasilannya pun menjadi tinggi (Gallan B. Mahesa, Damri, 2013). Pertama, Penyusunan RPP RPP merupakan rencana pembelajaran yang urgen untuk dirumuskan oleh guru sebelum mengajar. Salah satu faktor ketercapaian tujuan pembelajaran ialah dengan adanya RPP. Disisi lain, keurgenannya juga terlihat pada suatu pembelajaran yang disampaikan oleh guru menjadi lebih terarah. Untuk itu jika guru tidak membawa RPP ketika mengajar, maka kemungkinan besar pembelajarannya menjadi tidak terarah (Wawancara Nur Huda, 2018).

Namun problemnya, penyusunan RPP seperti yang diharapkan masih kurang maksimal, atau dengan istilah lain dikatakan masih meraba-raba. Penyebab lainnya juga dilatar belakangi oleh bergantinya mapel setiap tahun. Artinya ketika guru telah menemukan titik problem yang harus dibenahi hal itu menjadi tidak terealisasi. Hal itu menjadikan guru mengalami kebingungan dalam menentukan metode yang pas.

Kedua, Pelaksanaan pembelajaran Dalam pelaksanaan pembelajaran, dengan adanya RPP cukup sangat membantu proses pembelajaran. Hal itu juga berkaitan dengan tercapainya tujuan pembelajaran. Suatu keadaan antara guru yang membawa RPP dengan yang tidak cukup sangat terlihat dalam kendala yang dihadapi. Bagi guru yang tidak membawa RPP dapat dikatakan tidak membaca KD (kompetensi dasar) yang harus dicapai sebelum mengajar (Wawancara Nur Huda, 2018). Setiap proses pelaksanaan pembelajaran, terkadang masih akrab dengan kendala atau hambatan. Termasuk 
pula dalam pembelajaran PAI yakni pada Mapel Qur'an Hadits. Salah satu kendala yang dihadapi oleh guru terkadang hal yang direncanakan berbeda dengan kondisi di kelas, hal itu menyebabkan guru harus mengganti metode lain supaya pembelajaran tetap efektif dan kondusif.

Ketiga, Penilaian hasil belajar Hasil belajar peserta didik pada materi Qur'an Hadits dapat dikatakan meningkat meski belum signifikan. Sebagai langkah problem solving yang seharusnya dilaksanakan oleh guru tidak terealisasi, hal itu disebabkan selalu bergantinya mata pelajaran yang diampu oleh masing-masing guru di setiap tahunnya. Untuk itu guru menjadi tidak dapat fokus membenahi problem tersebut. Langkah-langkah guru PAI dalam melakukan penilaian, jika terdapat peserta didik yang lemah dalam ranah kognitifnya, yang dilakukan guru ialah menilainya dari ranah lain yaitu afektif dan psikomotorik peserta didik.

Salah satu penyebab peserta didik tidak mencapai KKM, yaitu:

b. Faktor bawaan sejak lahir

c. Tingkat kejenuhan

d. Hampir mendekati masa puber (bagi kelas 5 dan seterusnya) (Wawancara Nur Huda, 2018).

\section{Problem Pembelajaran PAI di MI Ma'arif Bego}

Berdasarkan wawancara dengan Bapak Nur Huda pengampu pelajaran PAI (Qur'an Hadits) kelas V di MI Ma'arif Bego terdapat beberapa kendala atau problem dalam mengimplementasikan dan mengembangkan kurikulum PAI di MI Ma'arif Bego. Problem tersebut, diantaranya:
1. Daya konsen peserta didik menurun, kemampuan anak untuk konsentrasi hanya mampu setengah jam.

2. Hampir mendekati masa remaja. Masa-masa peralihan tersebut dapat mengganggu konsentrasi pembelajaran di kelas, bias dari faktor lingkungan luar diri mereka seperti perkembangan IT dan factor pergaulan baik dengan teman sebaya dan lainnya (Wawancara Nur Huda, 2018).

\section{Strategi dalam Mengatasi Problem PAI}

Adapun strategi yang dilakukan oleh guru dalam mengatasi hambatan utamanya dalam proses pembelajaran PAI, diantaranya:

1) Memotivasi peserta didik supaya semangat belajar dan termotivasi untuk selalau belajar dan membaca.

2) Dari sisi rohani ialah dengan mendoakan peserta didiknya (Wawancara Nur Huda, 2018).

Salah satu bentuk implementasi kurikulum di MI Ma'arif Bego, selain dapat diketahui melalui proses pembelajaran di kelas seperti yang telah diuraikan berikut dengan problem yang dihadapi, terdapat pula beberapa hal yang dapat diketahui, yang disebut the bidden curriculum. Kurikulum tersembunyi, dapat diketahui dari hasil interaksi sosial antara murid dengan segala hal disekolah.

Proses penanaman nilai-nilai karakter kepada siswa seperti yang dimaksud dapat dilihat dari beragam kegiatan atau budaya peserta didik, semisal: Ketiga, Pembiasaan shalat Duha berjamaah Kegiatan ini merupakan kegiatan luhur, shalat duha yang dilakukan sebelum jam pelajaran pagi dimulai dapat menerapkan nilai-nilai 
keimanan kepad Allah sebab dibalik kesibukan, tidak lupa untuk menunaikan ibadah kepada Allah SWT. Keempat, Menjaga dan mencintai lingkungan bersih dan asri Menjaga kebersihan merupakan kegiatan yang terpuji, dan di MI Ma'arif Bego berusaha menanamkan nilai-nilai luhur untuk selalu menjag akebersihan yaitu dengan membuang sampah di tempatnya. Ketiga, Menanam tumbuhan yang dilakukan siswa bersama guru. Menanam tumbuhan merupakan kegiatan peduli terhadap lingkungan atau disebut pula dengan membudayakan kearifan lokal. Di MI Ma'arif Bego, peserta didik diminta untuk membawa tumbuhan baik itu sejenis bunga atau lainnya. Kemudian ditanam bersama-sama dengan guru. Setiap kelas memiliki tugas membawa bunga dengan jenis yang berbeda. Kegiatan menunjukkan bahwa MI Ma'arif Bego mengharapkan peserta didiknya memiliki kepedulian yang tinggi terhadap alam sekitar dan merawatnya untuk generasi selanjutnya. Keempat, Budaya bersikap sopan dan santun terhadap orang lain Budaya bersikap sopan dapat terlihat dari perilaku siswanya yang ramah terhadap orang lain atau sesama teman. Mereka pun saling membantu terhadap sesama. Keempat, Figur tenaga pendidikan yang bersahabat dan menginspiratif Figur tenaga pendidik yang bersahabat dilakukan oleh para guru, sehingga peserta didik dapat lebih akrab dengan para gurunya tanpa melebihi batasan. Tenaga kependidikan yang lain pun juga ditampakkan dengan memberikan layanan yang baik terhadap peserta didik.

\section{Kesimpulan}

Adapun kesimpulan dari hasil penjabaran serta analisis kurikulum di MI Ma'arif Bego, diantaranya: pertama, Bentuk implementasi kurikulum PAI di MI Ma'arif Bego terdapat dua hal, yaitu: a) kurikulum aktual meliputi kegiatan pembelajaran di kelas. Kegiatan tersebut diupayakan dengan mengkoordinasikan lingkungan supaya dapat tercipta perubahan perilaku peserta didik dan mampu mencapai kompetensi dasar. Penyusunan RPP merupakan hal yang urgen namun perlu perhatian serius bagi guru-guru supaya tujuan pembelajaran benar-benar terealisasi. b) Kurikulum tersembunyi yang dapat dilihat dari beragam kegiatan atau budaya peserta didik, yaitu pembiasaan shalat duha, Menjaga dan mencintai lingkungan bersih dan asri, Menanam tumbuhan yang dilakukan siswa bersama guru, bersikap sopan dan santun kepada orang lain figure tenaga pendidikan yang bersahabat. Kedua, Pelaksanaan pengembangan kurikulum PAI dapat dikatakan urgen, sebab pendidikan terus berkembang sesuai dengan pergantian zaman. Pengembangan juga harus mengikuti arah tersebut. Dalam pelaksanaanya, penyusunan RPP dapat membantu proses pembelajaran. Meski dalam penerapannya masih belum signifikan. Pelaksanaan tersebut juga dilakukan proses evaluasi untuk mengukur sejauh mana keberhasilan pembelajaran atau kompetensi peserta didik. Hal-hal yang dilakukan dalam mengevaluasi ialah tidak hanya menilai dari ranah kognitifnya saja, melainkan dari ranah afektif dan psikomotorik (untuk kelas IV, V dan VI). Ketiga, dari hasil wawancara dengan salah satu guru PAI di MI Ma'arif Bego dapat dikatakan proses implementasi kurikulum masih belum maksimal. Hal itu dikarenakan pelaksanaannya masih terkesan merabaraba, terdapat beberapa keluhan dari guru yang bersangkutan untuk menemukan solusi tepat semisal mengatasi kejenuhan peserta didik yang dilatar belakangi oleh faktor-faktor internal maupun eksternal. Artinya kompetensi professional guru belum mumpuni dibidang itu. Namun, jika dilihat dari sisi lainnya (implementasi kurikulum tersembunyi), semisal 
implementasi kegiatan program kelembagaan yaitu penanaman pohon, bersikap luhur, dan lainnya, peserta didik nampak bersemangat. Kelima, Kepada kepala sekolah, hendaknya memorivasi dan mendorong guru supaya lebih kreatif lagi dalam mengajar, menciptakan pembelajaran yang aktif dan inovatif, meningkatkan pengawasan, memberikan solusi terhadap problem yang dihadapi guru semisal penyususnan RPP. Selain itu kepala sekolah juga harus meningkatkan fasilitas dan sarana prasarana untuk mendukung pengembangan dan implementasi kurikulum PAI. Keenam, Kepada Waka Kurikulum supaya dapat mengembangkan dan mengorganisisr kurikulum supaya lebih baik lagi dan cepat dalam mengatasi problem yang terjadi. Ketujuh, Kepada guru, khususnya guru PAI, untuk lebih baik lagi dalam mengaja, meningkatkan kualitas mengajar dan dapat mengatasi kejenuhan peserta didik serta up to date terhadap perkembangan. Kemudian memotivasi peserta didik supaya mau membaca hingga memiliki kecintaan terhadap buku atau ilmu pengetahuan. Guru juga diharuskan memaksimalkan pembelajarannya dengan variasi metode dan strategi supaya tingkat kejenuhan peserta didik dapat terobati. Kedelapan, Kepada Peserta didik, supaya lebih giat dalam belajar dan rajin membaca buku supaya memiliki pengetahuan yang luas dan tidak hanya diperoleh di lingkungan sekolah, serta mematuhi segala peraturan yang dibuat oleh sekolah, sebab aturan tersebut dibuat untuk kebaikan bersama.

\section{Bibliography}

\section{Buku:}

Ansyar, Mohammad (2015), Kurikulum: Hakikat, Fondasi, Desain dan Pengembangan, Kencana, Jakarta.
C. Ornstein, Allan dan P. Hunkins, Francis (2009), Curriculum: Foundation, Principles, and Issues, Pearson, Amerika.

Ghony, M.Djunaidi, dan Almanshur, Fauzan (2014), Metodologi Penelitian Kualitatif, Ar-Ruzz Media, Yogyakarta.

Gunawan, Heri (2013), Kurikulum Dan Pembelajaran Pendidikan Agama Islam, Alfabeta, Bandung.

Hasan, S. Hamid (2009), Evaluasi Kurikulum, Remaja Rosdakarya, Bandung.

Hidayat (2013), Sholeh Pengembangan Kurikulum Baru, Remaja Rosdakarya, Bandung.

Idi, Abdullah (2014), pengembangan Kurikulum: Teori dan Praktik, Raja Grafindo persada, Jakarta.

J. Moleong, Lexy. (2010), Metodologi Penelitian Kualitatif, Remaja Rosdakarya, Bandung.

Mudlofir, Ali (2012), Aplikasi Pengembangan Kurikulum Tingkat Satuan Pendidikan dan Bahan Ajar Dalam Pendidikan Agama Islam, Raja Grafindo, Jakarta.

Muhaimin (2014), Pengembangan Kurikulum Pendidikan Agama Islam, Raja Grafindo, Jakarta.

Santoso, Sedya (2011), Kajian Kurikulum di Madrasah Ibtidaiyah, Yogyakarta: Fakultas Tarbiyah UIN Sunan Kalijaga, Yogyakarta.

Taba, Hilda (1962), Curriculum Development: Theory and Practice, Harcourt, Brace and World, INC, New York.

Tim Pengembang MKDP Kurikulum dan Pembelajaran (2011), Kurikulum dan Pembelajaran, Raja Grafindo Persada, Jakarta.

Zaini, Muhammad (2009),

Pengembangan Kurikulum: Konsep Implementasi, Evaluasi, dan Inovasi, Teras, Yogyakarta. 


\section{Jurnal}

Abong, Rustam (2015), "Konstelasi Kurikulum Pendidikan Indonesia," At-Turats, vol.9, no.2, hlm. 38, Pontianak.

Ahid, Nur (2006), "Konsep dan Teori Kurikulum dalam Dunia Pendidikan," Islamica, Vol.1, No. 1, hlm. 17, Surabaya.

Bahri, Syamsul (2011), "Pengembangan Kurikulum Dasar dan Tujuannya," Islam Futura, vol. xi, no. 1, hlm. 20, Aceh.

Dewantoro, M. Hajar (2003), "Pengembangan Kurikulum PAI," JPI FLAI Jurusan Tarbiyah, Vol. IX Tahun VI, hlm. 49, Yogyakarta.

Gellan, Damri, dan Azwandi, Yosfan (2013), "Rencana Pembelajaran oleh Guru di SMP Negeri 3 Padang dalam Setting Inklusi," E-Jupekhu Jurnal Imiah Pendidikan kehusus), vol. 2, no.3, hlm. 297, Padang.

Hidayatulloh, Arif, dkk. (2017), "Problematika K-13 dalam Pembelajaran PAI," Edudeena, Vol. 1 No. 2, hlm. 64, Kediri.

Irsad, Muhammad (2016), "Pengembangan Kurikulum Pendidikan Agama Islam di Madrasah (Studi Atas Pemikiran Muhaimin)," Iqra', vol. 2, No.1, hlm. 243, Lampung.

Juwairiyah (2004), "Kurikulum Ideal antara Cita dan Realita," jurnal Pendidikan Agama Islam, vol. 1, No.2, hlm. 203, Surabaya.

Katni (2016), "Hubungan JIwa Raga dengan Kurikulum Pendidikan Islam Menurut Ibnu Sina," al-Idarah, vol.6, No. 1, hlm. 31-33, Lampung.

Nurhalim, Muhammad (2014), "Optimalisasi Kurikulum Aktual dan Kurikulum Tersembunyi dalam Kurikulum 2013," Insania, vol.19, no. 1, hlm. 119-120, Purwokerto.
Rohman, Mujibur (2015), "Problematika Kurikulum Pendidikan Islam," Jurnal Madaniah, vol. VIII, hlm. 1, Pemalang.

\section{Wawancara}

Wawancara kepada Bapak Nur Huda, Guru PAI MI Ma'arif Bego Sleman, Yogyakarta, 14 Desember 2018. 